\title{
Fishermen's local ecological knowledge on Southeastern Brazilian coastal fishes: contributions to research, conservation, and management
}

\author{
Renato A. M. Silvano ${ }^{1,4}$ and Alpina Begossi $i^{2,3,4}$
}

\begin{abstract}
We analyzed fishermen's local ecological knowledge (LEK) about the feeding habits, trophic interactions, habitats, fishing grounds, migration, and reproduction of nine coastal fishes in Búzios Island, southeastern Brazilian coast. We interviewed 39 fishermen using standardized questionnaires. Fishermen's LEK on habitat use and trophic interactions for the studied fishes agreed with the scientific literature, allowing the organization of reef and pelagic food webs. The interviewed fishermen mentioned that submerged rock formations would be important habitats for some large commercial fishes, such as Seriola spp., Caranx latus and Epinephelus marginatus. In some instances there was no scientific data to be compared with fishermen's LEK, and thus this kind of knowledge would be the only available source of information, such as for reproduction and migration of most of the studied fishes. We suggest herein ways to apply fishermen's LEK to develop and improve fisheries management measures, such as zoning of marine space, marine protected areas, and closed fishing seasons. Fishermen's LEK may be an important and feasible support to fisheries management and co-management.
\end{abstract}

Analisamos o conhecimento ecológico local (CEL) dos pescadores sobre os hábitos alimentares, interações tróficas, habitats, locais de pesca, migração e reprodução de nove peixes costeiros na Ilha de Búzios, litoral sudeste do Brasil. Entrevistamos 39 pescadores, utilizando questionários padronizados. As informações sobre uso do habitat e interações tróficas entre os peixes estudados com base no CEL dos pescadores foram condizentes com a literatura científica, permitindo a organização de teias tróficas para os habitats recifal e pelágico. Os pescadores entrevistados mencionaram que formações de rochas submersas seriam habitats importantes para alguns peixes comerciais de grande porte, como Seriola spp., Caranx latus e Epinephelus marginatus. Em algumas circunstâncias, não haviam dados biológicos para serem comparados com o CEL dos pescadores, que, portanto seria a única fonte disponível de informação, por exemplo sobre a reprodução e migração de vários dos peixes estudados. Sugerimos aqui formas de aplicar o CEL dos pescadores para desenvolver e aprimorar medidas de manejo pesqueiro, como zoneamento do espaço marinho, áreas marinhas protegidas e épocas de defeso da pesca. O CEL dos pescadores pode ser um apoio importante e factível para iniciativas de manejo e co-manejo pesqueiro.

Key words: Ethnobiology, Fish behavior, Fish ecology, Human ecology, Small-scale fisheries.

\section{Introduction}

In order to deal with increasingly environmental uncertainties and complex, multi-species fisheries, fisheries management should ideally be ecosystem based, adaptive and precautionary, being implemented even if managers have incomplete biological data (Johannes, 1998; Pauly et al., 2002). Many tropical developing countries lack the scientific information needed to manage coastal fisheries. These fisheries may have thus to be managed following a "data less" approach, which includes all available biological data plus inputs from fishermen's local ecological knowledge (LEK) (Johannes, 1998). Indeed, several studies have been analyzing fisher's LEK and comparing it with available scientific ecological research; these studies contribute to improve the knowledge about ecology, migration, reproduction, feeding habits, and changes in abundance of a diverse array of fishing resources, ranging from fish to whales (Johannes, 1981; Poizat \& Baran, 1997; Johannes et al., 2000; Huntington et al., 2004; Sa'enz-Arroyo et al., 2005; Silvano et al., 2008, 2009). Therefore, studies on fishers' LEK may be useful to develop new and testable biological hypotheses (Silvano \& Valbo-

\footnotetext{
${ }^{1}$ Universidade Federal do Rio Grande do Sul, Departamento de Ecologia, CP 15007, 91501-970 Porto Alegre, RS, Brazil. renato.silvano@ufrgs.br

${ }^{2}$ Universidade Santa Cecília/UNISANTA, ECOMAR, 11045-040 Santos, SP, Brazil.

${ }^{3}$ Universidade de Campinas, CAPESCA, PREAC \& CMU, Rua Sergio Buarque de Holanda 800, Cidade Universitária, CP 6023, 13083 859, Campinas, SP, Brazil, alpinab@uol.com.br

${ }^{4}$ Universidade de Santa Cecília/UNISANTA, Fisheries and Food Institute (FIFO), 11045-040 Santos, SP, Brazil.
} 
Jørgensen, 2008), generating data to support either conventional or common based fisheries management systems (Ruddle \& Hickey, 2008).

Brazilian small-scale coastal fishermen exploit several fish species, most of which are still poorly known regarding their biology and ecology. Furthermore, there are few data on fish landings and small-scale local fishermen have often been neglected by governmental management measures (Begossi, 1998, 2006; Diegues, 1998). Such situation is typical of coastal fisheries in tropical developing countries (Ruddle \& Hickey, 2008). The data-less approach to fisheries management (Johannes, 1998) may be thus appropriate to the Brazilian coast too, where fishermen usually have a detailed knowledge about fish (Marques, 1991; Silvano \& Begossi, 2005; Gerhardinger et al., 2009).

Previous studies have analyzed relevant topics related to fishers' LEK in the Brazilian coast, such as fish reproduction (Silvano et al., 2006), migration (Silvano \& Begossi, 2005), and ecology of endangered reef fish (Gerhardinger et al., 2009). Some of these surveys addressed both fishers' LEK and biological studies of coastal fishes (Begossi \& Silvano, 2008; Silvano \& Begossi, 2010). Fishers' LEK on these and other topics could potentially improve fishery management, but there are relatively few published surveys addressing the ethnoecology of coastal fishes with a focus on its application in management and conservation. In this study, we record and discuss fishermen's LEK in a manner understandable to biological scientists and fisheries' managers, who could thus apply these results to improve (or create) management measures. Our results may be also useful to enhance dialogue and cooperation between fishers and managers, setting a favorable scenario for future development of co-management at the southeastern Brazilian coast and in other tropical coastal areas. Our major aim is to analyze LEK of fishermen in a Brazilian coastal island and to compare this LEK with available biological information from the literature, looking for potential new insights, therefore helping to improve fisheries management measures in the studied region (southeastern Brazilian coast).

\section{Material and Methods}

Study Area. The study was conducted at Búzios Island, located off the coast of São Paulo State, southeastern Brazilian coast $\left(23^{\circ} 47^{\prime} \mathrm{S} 45^{\circ} 10^{\prime} \mathrm{W}\right)$. This island has rocky shores and is located about $24 \mathrm{~km}$ from the mainland (city of São Sebastião); details of the study site are in Begossi (1996), Silvano (2001), Silvano \& Begossi (2005). This island and its surrounding region are included in the State Park of Serra do Mar, a conservation area created to protect the remaining tracts of Atlantic Forest vegetation in the southeastern Brazilian coast, which has raised conflicts between governmental management agencies and local people (Diegues, 1998; Begossi, 1998, 2006).

The marine coastal environment surrounding Búzios Island consists on a continental shelf including sandy and rocky bottoms and rocky shores (subtropical rocky reefs).
The fish fauna around the island includes reef fish, open water pelagic fishes and demersal fishes (Figueiredo \& Menezes, 1978, 1980, 2000; Silvano, 2001; Silvano \& Güth, 2006). Búzios Island and the surrounding continental shelf have about 127 fish species, 44 of which are used by fishermen for food, commerce, bait, or medicinal purposes (Begossi, 1992, 1996; Begossi \& Figueiredo, 1995).

Studied fishing community. The local people living along the southeastern Brazilian coast are called Caiçaras, who descend from Tupinamba indians (indigenous Brazilians) and Portuguese colonizers, besides showing influences of other cultures, such as Africans and Japanese. The Caiçaras' economic activities have been changing from agriculture (beginning of the last century till the mid of 1950s) to fishing and recently to tourism as well (Begossi, 1998, 2006).

Local people living in Buzios Island are typical Caiçaras, who were relatively isolated from the mainland society at the time of this survey (1998-2000), because the island is far from the coast and had no tourism development (Begossi, 1996). Búzios Island Caiçaras, the same way as Caiçaras in general (Adams, 2000), are devoted to small-scale agriculture and fishing. However, at the time of the present study, Búzios Island Caiçaras relied mainly on coastal fisheries as a source of food and income (Begossi, 1996, 1998; Silvano \& Begossi, 2005). Búzios Island fishermen are socially organized in kin ties, which usually include members of a same family living clustered on the island (Begossi, 2006). There is a labor division, also typical of Caiçara communities, in this island: men do most of the fishing, especially the commercial boat fishing in open water, whereas women are mostly engaged in house care, small-scale agriculture, and occasionally engage in subsistence fishing from the shore (Begossi, 1996).

Búzios Island fishermen use paddled canoes or motorized boats, to catch mainly squid and fish by using hand lines and gillnets. Fish and squid caught are sold both in the island (to fish buyers) and in markets at the nearby coastal cities of Ilha Bela and São Sebastião (Begossi, 1996, 2001). Búzios Island fishermen use two main fishing techniques: "Lambreta", a kind of artificial bait made from nylon skirts to catch the bluefish (locally named Enchova) (Pomatomus saltatrix, Pomatomidae); and "Jangarelho", which consists of several hooks attached to each other to catch squids (locally named Lulas) (Loligo spp.). Bluefish and squids are the two most important fishing resources in Búzios Island, considering availability and market value. Other important commercial fish exploited in this island are the amberjack (Seriola spp.) and groupers (Epinephelus spp. and Mycteroperca spp.) (Begossi, 1996, 2001; Begossi \& Richerson, 1993). Besides its commercial importance, fish is also the main source of animal protein consumed in Búzios Island (Begossi \& Richerson, 1993). Búzios Island fishermen show a detailed knowledge on fish classification and nomenclature (Begossi \& Figueiredo, 1995). These Caiçaras show also cultural relationships with fishes, as some fish are used for medicinal purposes, some are food taboos and some are recommended to be consumed 
by ill persons (Begossi, 1992). Búzios Island fishing community could be regarded as an ideal setting to study fishermen's LEK on fish, because this Caiçara community is relatively isolated from outside influences, is highly devoted to fishing, and exploits a coastal environment rich on fish species, many of which remain poorly known to biologists.

Sampling Method. The survey of fishermen's LEK in Búzios Island was conducted during 56 non-consecutive days, from 1998 to 2000. Due to the labor division in Búzios Island (see above), only adult men (older than 18 years) were included in this study. Women may also have relevant LEK about fish, because women are the ones who usually clean and cook the fish. Additionally, women engage in fishing from the shore using pole and line. Nevertheless, women were excluded from this study due to logistic and cost-benefit constraints: given the length of interviews and the difficulties to find interviewees, we opted for a larger male sample. Furthermore, the men, who are in charge of fishing, could show more detailed and thus useful LEK to fisheries management.

We sampled accessible localities in the island, where most of the fishermen live, excluding from the survey more distant and inaccessible places. We interviewed 39 fishermen, including the majority (about $80 \%$ ) of island fishermen population, estimated to be around 45 adults (Begossi, 1996). Some of these resident adult fishermen could not be found and some of them declined to participate in this survey. At the time of the study, the interviewees were between 19 and 80 years old, with an average age of 42 years (Silvano \& Begossi, 2005).

We selected nine fish species to be addressed in the interviews with fishermen (Table 1). All these fishes are common at the study site and they represent distinct ecological and fishery characteristics of the regional ichthyofauna, such as large and small fish, fishes with low and high economic value, reef and pelagic fishes (Table 1). A subset of 28 fishermen (out of the 39 total interviewed) were interviewed about some of the fish species studied (Table 1), because we could not complete the survey with all fishermen. The bluefish was also included in this study, but the results concerning this fish are in Silvano \& Begossi (2005), which includes interviews with Australian fishermen about this same species. Therefore, bluefish results will be analyzed here only when addressing throphic relationships.

Data collection: interviews. Data on fishermen's LEK were gathered through interviews using standardized questionnaires with 13 questions about the studied fishes (Table 1): 1) Which is the name of this fish (common name)? 2) For what is it used for? 3) How do you catch it (fishing gear and baits)? 4) Do you catch it during the day or during the night? 5) Is it active (swimming) during the day or during the night? 6) Where do you catch it (fishing grounds) or where it can be found? 7) When do you catch it, or when does it appear (seasonal occurrence)? 8) From where does it come and to where does it go (migratory behavior)? 9) Does it form schools? 10) Where does it live (habitats)? 11) What does it eat (feeding habits)? 12) Does another fish or animal eat it (predators)? 13) When does it breed, or when does it appear with eggs (reproduction)? All these questions were asked as open ended questions, in the same way and in a form understandable by the interviewed fishermen. The question 10 (fish habitats) was formerly presented as open ended, but we further offered some habitat categories to fishermen: reefs, open sea (pelagic), surface, bottom, sand. Before each interview, we explained the overall scope of the study and always asked for the interviewee's consent. Fish species were presented as color photographs, in the same randomized order to all fishermen. These interview methods have been successfully adopted in previous surveys (Silvano \& Begossi, 2005; Silvano et al., 2006, 2008).

Data analysis. The data gathered during interviews were quantified as percent of interviewees that mentioned a given answer (frequencies). We reported in Tables only information mentioned by more than $15 \%$ of interviewees for at least one of the studied fish species. Therefore, analyses were concentrated on main patterns, following a quantitative approach (Silvano et al., 2008). We made multivariate correspondence analyzes to show the main patterns of data cited by fishermen: in all these analyses, the sampling units were the information mentioned (Table 2) and the nine studied fishes, which were both grouped based on the percentage of fishermen who mentioned each information. These analyzes were made with chi-square distance measures and using the PC-ORD software (McCune \& Mefford, 1997). In some of these analyses, we used only data cited by more than $4 \%$ of the interviewed fishermen, to facilitate interpretation. The answer 'I don't know' was not included in the correspondence analysis.

When in doubt regarding which data were cited more often by fishermen, we made chi-square statistical tests, which were based on the number of fishermen mentioning each data, not on percentages. We also analyzed the number of 'doubts', or situations on which the interviewee mentioned he don't know the answer for a given question, following approach by Silvano \& Begossi (2002). We compared the number of doubts about fish reproduction among fish species using percentages, due to the different number of interviewees for each fish species (Table 1).

\section{Results}

Fish uses and fishing methods. The results of ordination analyses are summarized in Table 2, which shows eigenvalues of the first two ordination axes, which were plotted to show data patterns. The magnitude of the eigenvalue is related to the relative amount of variance in the data set explained by each ordination axis. Overall, most of the variation was usually explained by the first ordination axis (Table 2). The eigenvalues of the ordinations regarding reproductive seasons and migratory routes were low (Table 2), which indicated that most of the variation in the data set was not explained by these analyses. 
Table 1. Fish species addressed in interviews with Búzios Island fishermen: common name in English according to (Froese \& Pauly, 2011), total number of interviewed fishermen (N), mean size based on measures of Standard Length (SL) of fishes at the study site, main habitat and estimated value for commerce and food (high, medium, low) based on previous surveys (Begossi, 1992, 1996; Begossi \& Richerson, 1993; Begossi \& Figueiredo, 1995). Common name of Seriola spp. and Kyphosus spp. corresponded to more than one species. Amberjack, dusk grouper and horse-eye jack measured were possibly juveniles.

\begin{tabular}{|c|c|c|c|c|c|c|c|}
\hline Common name & Fish species & Family & Local Name & $\mathrm{N}$ & $\begin{array}{l}\text { Mean size } \\
(\mathrm{SL} \mathrm{cm})\end{array}$ & Habitat & Value \\
\hline Amberjack & Seriola spp. & Carangidae & Olho de boi & 28 & 26.1 & Pelagic & High \\
\hline Dusk grouper & $\begin{array}{l}\text { Epinephelus marginatus } \\
\text { (Lowe, 1834) }\end{array}$ & Serranidae & Garoupa verdadeira & 39 & 21.8 & Reef & High \\
\hline Balao halfbeak & $\begin{array}{l}\text { Hemiramphus balao } \\
\text { Lesueur, } 1821\end{array}$ & Hemiramphidae & Panaguaiú & 28 & 23.5 & Pelagic & Medium \\
\hline Horse-eye jack & Caranx latus Agassiz, 1831 & Carangidae & Xaréu & 39 & 13.4 & Pelagic & Medium \\
\hline Whitemouth croaker & $\begin{array}{l}\text { Micropogonias furnieri } \\
\text { (Desmarest, 1823) }\end{array}$ & Sciaenidae & Corvina & 28 & 28.5 & Demersal & Medium \\
\hline Sea chub & Kyphosus spp. & Kyphosidae & Pirajica & 39 & 16.8 & Reef & Medium \\
\hline Sergeant major & $\begin{array}{l}\text { Abudefduf saxatilis } \\
\text { (Linnaeus, 1758) }\end{array}$ & Pomacentridae & Tinhuna & 28 & 14 & Reef & Low \\
\hline Tomtate grunt & $\begin{array}{l}\text { Haemulon aurolineatum } \\
\text { Cuvier, } 1830\end{array}$ & Haemulidae & Corcoroca & 28 & 15.4 & Reef & Low \\
\hline Spanish hogfish & Bodianus rufus (Linnaeus, 1758) & Labridae & Bodião batata & 39 & 16.5 & Reef & Low \\
\hline
\end{tabular}

Fishermen provided a large amount of data on fishing related aspects of the studied species and we thus analyzed only those results considered as more relevant to management measures. Nearly all of the studied fishes were mentioned by the interviewed fishermen as being useful in some way. The most cited fishes as useful for market (\% of interviewed fishers) were Seriola spp. (100\%), Epinephelus marginatus (100\%), Caranx latus (92\%), Micropogonias furnieri (96\%) and Kyphosus spp. (74\%), although the former two fishes have higher market value than the other three, which were usually considered as low valued fish (Fig. 1). The Bodianus rufus was often mentioned by fishermen (92\%) as being useful as food; the Hemiramphus balao (100\%) and Haemulon aurolineatum (100\%) were often mentioned as bait, while the Abudefduf saxatilis was the only fish that was most mentioned as useless (43\%) (Fig. 1).

Table 2. Results of multivariate correspondence analyses based on percentage of interviewed fishermen who cited each of the information related to topics analyzed: numbers of eigenvalues are related to the amount of variance in the data set explained by each ordination axis (from 0 to 1 ). The corresponding ordination plots are shown in the figures and the raw data (percentages) are shown in Appendices.

\begin{tabular}{lccc}
\hline & & \multicolumn{2}{c}{ Eigenvalues } \\
\cline { 3 - 4 } Analysis (topic) & $\begin{array}{c}\text { Sampling units } \\
\text { and raw data }\end{array}$ & Axis 1 & Axis 2 \\
\hline Uses & Fig. 1 & 0.44 & 0.16 \\
Fishing methods and baits & Fig. 2 & 0.57 & 0.42 \\
Migratory behavior & Fig. 5 & 0.32 & 0.09 \\
Migratory routes & Fig. 6 & 0.21 & 0.12 \\
Fishing season & Fig. 7 & 0.34 & 0.16 \\
Reproductive season & Fig. 8 & 0.07 & 0.03 \\
\hline
\end{tabular}

The most cited fishing methods and baits also differed among the commercial fishes: Seriola spp. (100\%), E. marginatus (87\%) and C. latus (64\%) were said to be caught mainly with hand line techniques and using fishes and mollusks as bait; M. furnieri (100\%) and Kyphosus spp.(82\%) were usually caught using gill nets and H. balao (89\%) was caught using driftnets (Fig. 2).

Fish habitats. Fishermen indicated four major habitats for the nine studied fishes: island rocky reefs, which were mentioned mainly for B. rufus, $H$. aurolineatum, Kyphosus spp. and $A$. saxatilis; parcéis (submerged bottom rocks), which were mentioned for Seriola spp. and E. marginatus; some fishes, such as $H$. balao and C. latus (also mentioned as occurring in parcéis), were mentioned to occur both near Búzios Island reefs and in the open ocean; $M$. furnieri was mentioned to occur near the sand bottom in the open ocean. Regarding the fish vertical distribution along the water column according to fishermen, E. marginatus and $H$. aurolineatum occupy the bottom, H. balao and B. rufus occur near the surface (shallow), A. saxatilis and Kyphosus spp. make vertical migrations (Fig. 3 and Appendix 1).

Fish diet and fish feeding interactions. Fishermen's answers about feeding habits and predators of the studied fishes were organized in two simplified models of food-webs for reef (Fig. 4a) and pelagic (Fig. 4b) fishes. Most of the feeding interactions reported by fishermen agreed with data from the biological literature on fish diet (Fig. 4a,b), indicating that these food-webs are supported by these two knowledge bases. Furthermore, estimated trophic levels of the studied fishes based on fishermen's LEK data (Fig. 4a,b) were similar to the trophic levels based on biological data, but those levels based on fishermen's LEK were usually lower (Table 3). 


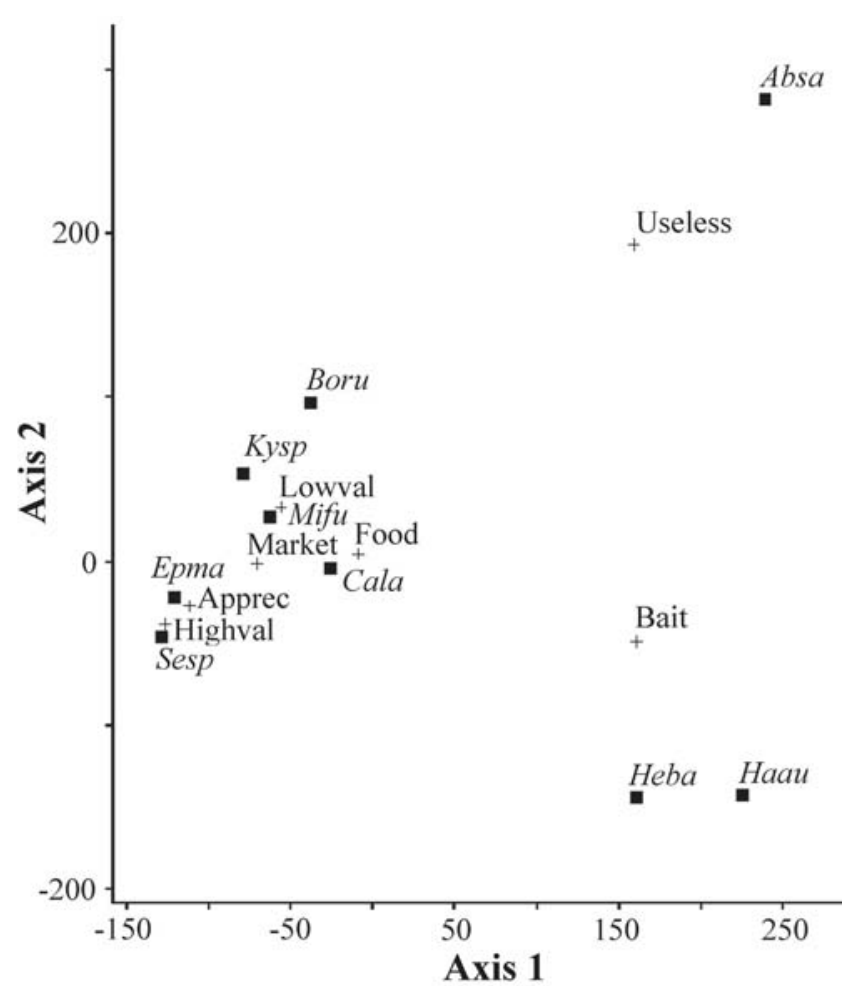

Fig. 1. Ordination plot of the correspondence analysis (first two axes) based on fishermen answers about uses of the nine studied fish species in the southeastern Brazilian coast: Absa $=$ Abudefduf saxatilis $;$ Boru $=$ Bodianus rufus $;$ Cala $=$ Caranx latus; Epma = Epinephelus marginatus; Haau = Haemulon aurolineatum; Heba = Hemiramphus balao; Kysp = Kyphosus spp.; Mifu = Micropogonias furnieri; Sesp = Seriola spp.

Fish schooling behavior and fish migration. The majority of fishermen mentioned schooling behavior for almost all the studied fishes, but E. marginatus (49\%) and B. rufus (59\%) were also mentioned as being solitary (Fig. 5). Furthermore, some fishermen mentioned that both B. rufus (28\%) and E. marginatus $(18 \%)$ occur in small groups of two to five individuals.

The majority of interviewed fishermen considered Kyphosus spp., C. latus, Seriola spp. and H. balao $\left(\chi^{2}{ }_{1}=7.3, \mathrm{p}<0.01\right)$ as migratory fishes, while $B$. rufus $\left(\chi_{1}^{2}=13.9, \mathrm{p}<0.01\right)$ and $A$. saxatilis $\left(\chi_{1}^{2}=9.5, \mathrm{p}<0.01\right)$ were mentioned mainly as being sedentary fishes; other fishes, such as M. furnieri, E. marginatus and $H$. aurolineatum were in an intermediate position regarding the migratory to sedentary continuum (Fig. 5).

According to fishermen some fishes, such as $E$. marginatus and $H$. aurolineatum, make short migrations around Búzios Island rocky shores. On the other hand, commercial fishes, such as Seriola spp., M. furnieri and $C$. latus, make longer migrations to and from the Búzios Island, offshore waters and parcéis (Fig. 6).

Fish seasonal occurrence. The correspondence analysis distinguished those fishes that occur year round according

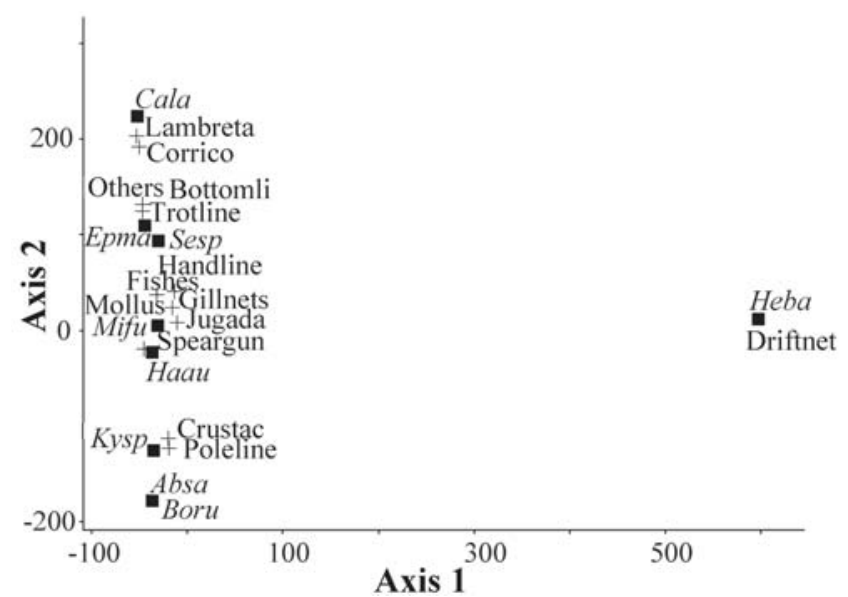

Fig. 2. Ordination plots of the correspondence analysis (first two axes) based on fishermen answers about fishing methods and baits of the nine studied fish species in the southeastern Brazilian coast: Absa $=$ Abudefduf saxatilis; Boru $=$ Bodianus rufus; Cala = Caranx latus; Epma = Epinephelus marginatus; Haau = Haemulon aurolineatum; Heba = Hemiramphus balao; Kysp = Kyphosus spp.; Mifu= Micropogonias furnieri; Sesp = Seriola $\mathrm{spp}$.

to fishermen (B. rufus, H. aurolineatum and A. saxatilis) from others that show seasonal occurrence (Fig. 7). The majority of interviewed fishermen mentioned that Kyphosus spp. (72\%), M. furnieri $(79 \%)$ and $\mathrm{H}$. balao $(50 \%)$ are usually caught during the cold season, while Seriola spp. (57\%), E. marginatus $(49 \%)$ and C. latus $(38 \%)$ are caught during the hot season (Fig. 7). May and June were the most mentioned fishing months for Kyphosus spp. (44\% and 51\% of fishermen respectively) and $M$. furnieri ( $46 \%$ and $61 \%)$.

Fish reproduction. The majority of the interviewed fishermen did not know the reproductive season of the studied fish species with the exception of $H$. balao: compared to the other fishes, fewer fishermen (32\%) did not know the reproductive season of this fish $\left(\chi_{8}^{2}=24.7, \mathrm{p}<0.01\right)$.

Fishermen answers indicated that all fishes would be spawning mainly during the hot season, except for $E$. marginatus and Kyphosus spp., which were mentioned as spawning during both hot (31\% and $15 \%$ respectively) and cold seasons (13\% and 8\%) (Fig. 8). Few fishermen mentioned spawning months of the studied fishes, but January was the most mentioned spawning month for Seriola spp. (11\%), E. marginatus (23\%), H. aurolineatum (32\%), M. furnieri (14\%) and A. saxatilis (21\%).

Temporal patterns of fish abundance. Although not asked to do so, some fishermen spontaneously mentioned trends on fish abundance, indicating that some commercial fishes, such as Seriola spp., E. marginatus and C. latus, had their abundance decreased, mainly due to over-fishing by both divers and large fishing boats (Table 4). 


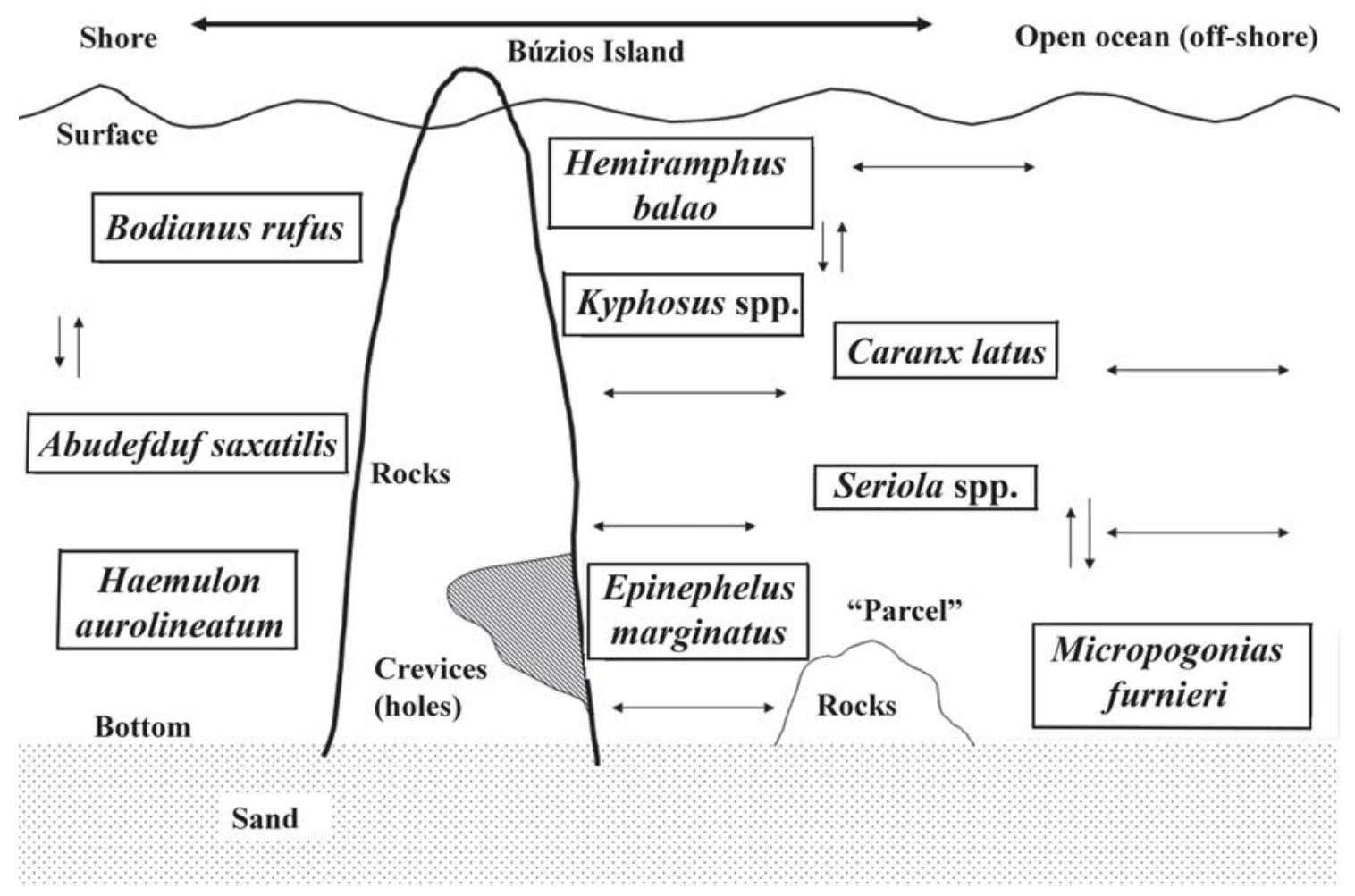

Fig. 3. Main habitats of fishes according to fishermen in the southeastern Brazilian coast: percentages of fishermen who mentioned each habitat category are in Appendix 1. Double-headed arrows indicate that fishes occur in both habitats in horizontal space (e.g. open ocean and reefs), up and down arrows indicate that fishes occur in both habitats in vertical space (e.g., near the bottom and at the surface). Fish sizes are not in scale.

\section{Discussion}

Reliability and accuracy of fishermen's LEK. We analyzed fishermen's LEK to improve fish and fisheries related research and management, according to the data less approach to fisheries management (Johannes, 1998). Since the classical study by Morril (1967), several other studies have recorded that small-scale fishermen have a detailed LEK about fish (Johannes, 1981; Johannes et al., 2000; Poizat \& Baran, 1997; Aswani \& Hamilton, 2004; Silvano \& Begossi, 2005; Silvano et al., 2006; Gerhardinger et al., 2009). Notwithstanding the methodological improvements on data collection, two recent issues on LEK research deserve consideration: reliability and accuracy (Maurstad et al., 2007). Reliability is the confidence that interviewees (fishermen in this study) are mentioning what they really know and believe, while accuracy is the degree to which the information provided by interviewees, even if reliable, corresponds to real biological phenomena (Maurstad et al., 2007). Therefore, a reliable (sincere) information given by an informant may be inaccurate (equivocal) and vice-versa. Reliability may be assessed by checking if the information given by fishermen is really based on their daily fishing practices, while accuracy may be checked by comparing fishermen's LEK with biological data (Maurstad et al., 2007). In this sense, we consider that the LEK of Búzios Island fishermen was reliable, because it is directly related to their daily fishing practices. Those organisms mentioned as fish baits by the interviewed fishermen were also mentioned as fish food (Fig. 4a,b), thus indicating a link between LEK on fish diet and bait choice. A similar coherence on fish baits and fish food has been also observed in a previous survey comparing the LEK of fishermen from Búzios Island and North Stradbroke Island (Australia) about the bluefish (Silvano \& Begossi, 2005). We also considered that the Búzios Island fishermen's LEK is reliable and accurate because it is consistent with fishers' LEK observed in other fishing communities, both in Brazil and other countries (Silvano \& Begossi, 2005, 2010; Silvano et al., 2006).

Fishermen's LEK and biological literature. Fishermen's LEK should not be accepted uncritically; it should be analyzed and interpreted by comparing it with biological data, as both LEK and biological knowledge are complimentary sources of information (Aswani \& Hamilton, 2004; Begossi \& Silvano, 
a

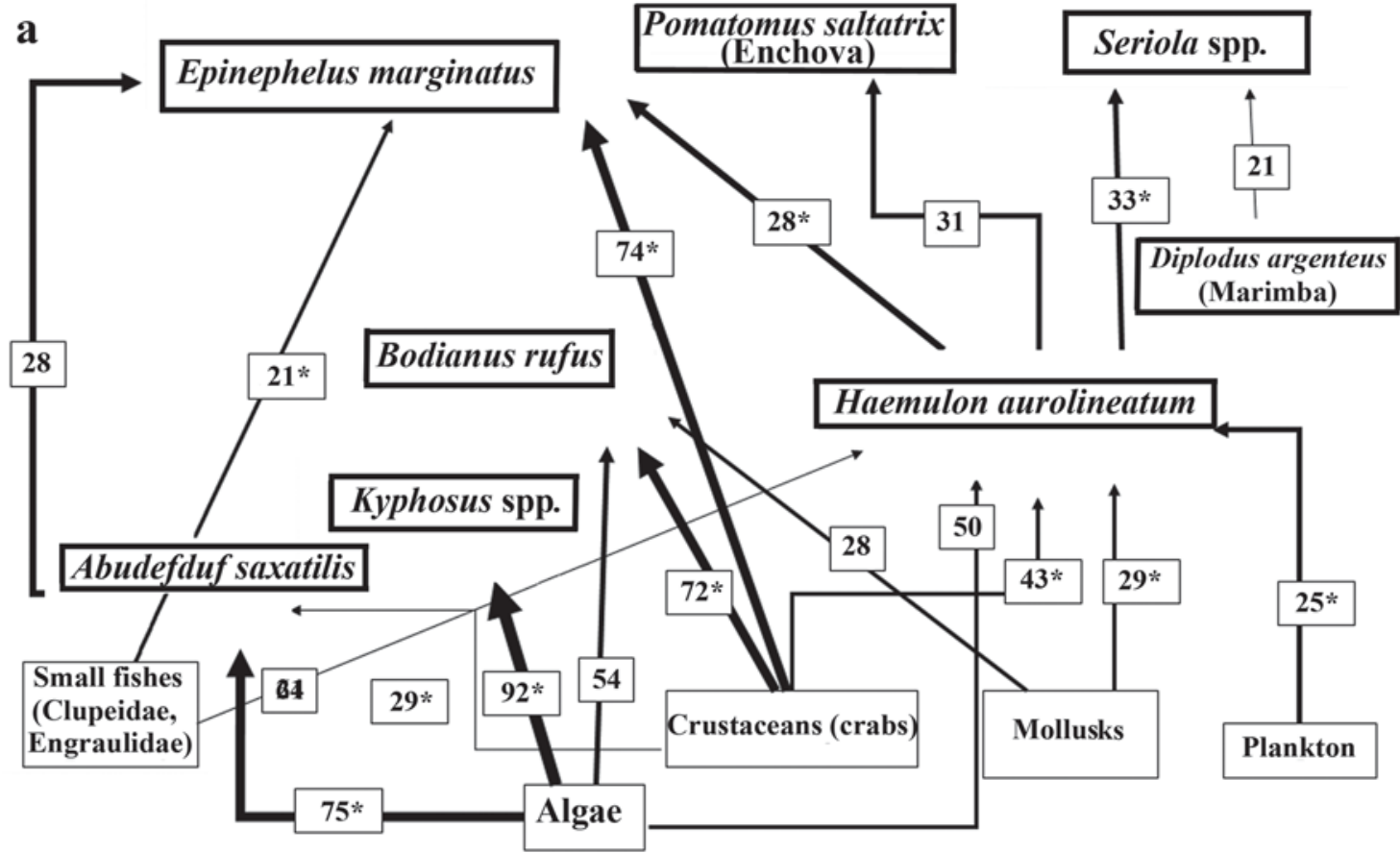

b

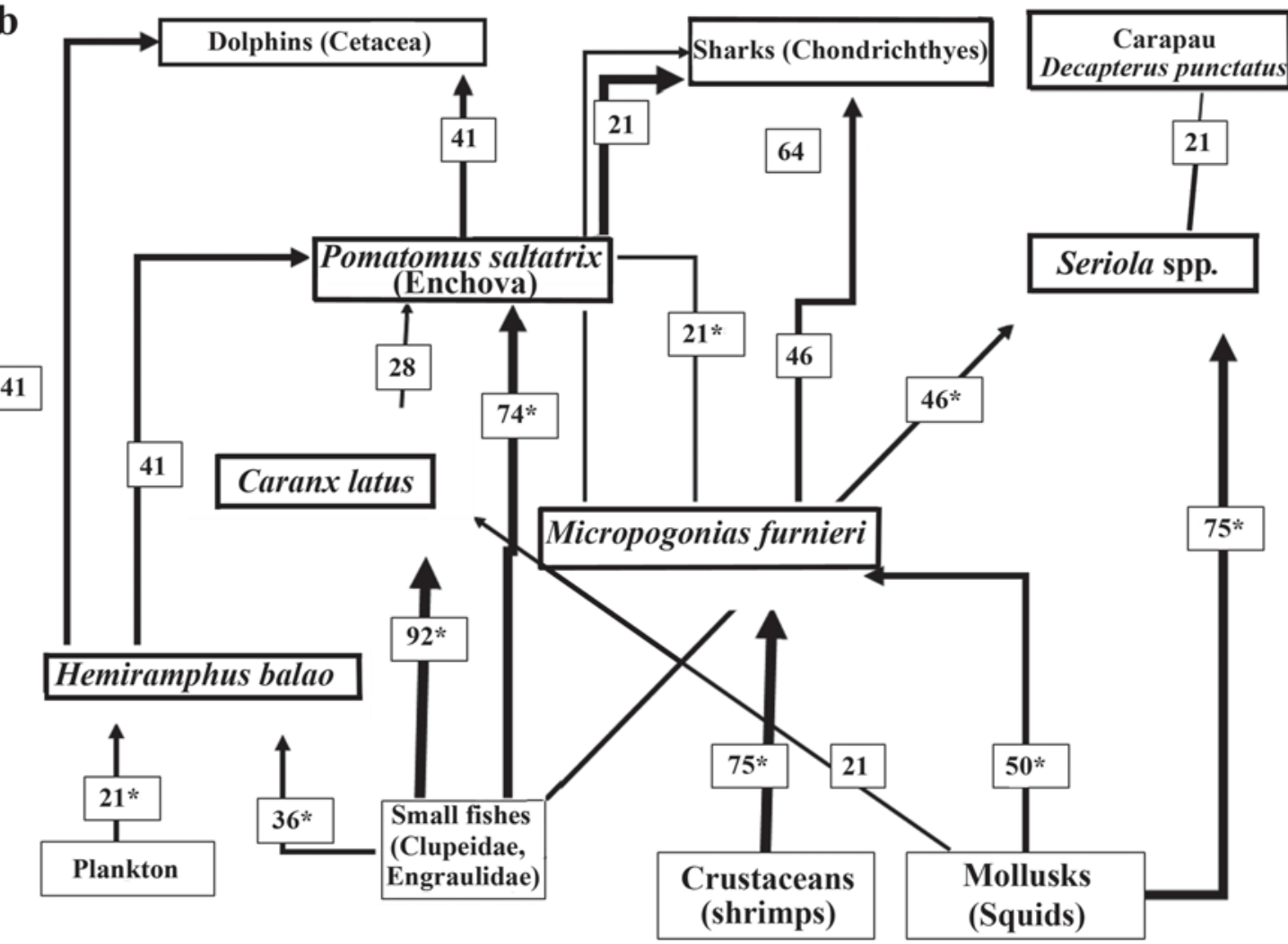

Fig. 4. Trophic chain based on those food items and predators most cited by fishermen in the southeastern Brazilian coast for $\mathbf{a})$ reef fishes and $\mathbf{b}$ ) pelagic fishes. Numbers are percent of interviewed fishermen who mentioned each feeding interaction. Fish sizes are not in scale. Those feeding interactions that agree with reported feeding habits of these fishes in the biological literature are marked *(Randall, 1967; Berkeley \& Houde, 1978; Menezes \& Figueiredo, 1980; Sazima, 1986; Pipitone \& Andaloro, 1995; Barreiros \& Santos, 1998; Vasconcellos \& Gasalla, 2001; Silvano, 2001; Silvano \& Güth, 2006; Figueiredo \& Vieira, 2005; Gibran, 2007). 
Table 3. Trophic levels for the nine studied fish species based on data gathered from the interviewed fishermen in Búzios Island and from the biological literature (Froese \& Pauly, 2011).

\begin{tabular}{lcc}
\hline \multicolumn{1}{c}{ Fishes } & Trophic level literature & $\begin{array}{c}\text { Trophic level } \\
\text { fishermen }\end{array}$ \\
\hline Kyphosus spp. & 2 & 2 \\
Epinephelus marginatus & 3.7 & 3.6 \\
Caranx latus & 4.4 & 3.8 \\
Bodianus rufus & 3.4 & 2.7 \\
Micropogonias furnieri & 2.6 & 3 \\
Seriola spp. & 4.5 & 3.76 \\
Hemiramphus balao & 3.6 & 3.25 \\
Abudefduf saxatilis & 3.4 & 2.5 \\
Haemulon aurolineatum & 4.4 & 2.8 \\
\hline
\end{tabular}

2008; Silvano \& Valbo-Jørgensen, 2008; Silvano \& Begossi, 2010). For example, regarding migratory fishing resources, such as whales, fishermen may provide information in a local scale, whereas biological surveys address a larger spatial scale (Huntington et al., 2004). Studies on fishermen's LEK may also help to better define sampling designs for future biological surveys (Poizat \& Baran, 1997). For example, LEK data from coastal and freshwater fishers from Brazil (including Búzios Island) and Southeast Asia provided new biological hypotheses about fish ecology (Silvano \& Valbo-Jørgensen, 2008). Comparison of fishermen's LEK with biological data might lead to three possible outcomes (Silvano \& Valbo-Jørgensen, 2008), which are discussed bellow.

Fishermen's LEK agrees with biological data. Most of the fish feeding habits mentioned by the Búzios Island fishermen corresponded to fish diet according to the biological literature (Fig. 4a, b). For example, most of the interviewed fishermen (92\%) mentioned that Kyphosus spp. eats algae (Fig. 4a). According to previous biological surveys, which analyze fish diet and feeding behavior, Kyphosus spp. browse algae on the rocks in the southeastern Brazilian coast (including the Búzios Island) (Sazima, 1986; Silvano \& Güth, 2006). Indeed, these fishes are important herbivores in southeastern Brazilian reefs (Ferreira et al., 2004). Figueiredo \& Vieira (2005) analyzed stomach contents of 415 individuals of $M$. furnieri in a south Brazilian estuary, observing that this fish eats mainly crustaceans; this same feeding habit was also mentioned for this fish species by most of the interviewed fishermen (75\%) (Fig. 4b). A recent survey indicates that E. marginatus eats mainly crabs at the studied region (southeastern Brazilian coast) (Gibran, 2007), which matches the diet of this fish species mentioned by most of the interviewed fishermen (74\%) (Fig. 4a). Other survey also reports crabs as the main food item of E. marginatus in southeastern Brazil, based on analyses of fish stomach contents and on fishers' LEK (Begossi \& Silvano, 2008).

The information provided by the Búzios Island fishermen about E. marginatus (sedentary fish, which occurs near the bottom, always associated with rocky shores or reefs and usually inside or at the entrance of crevices, Fig. 3) was of

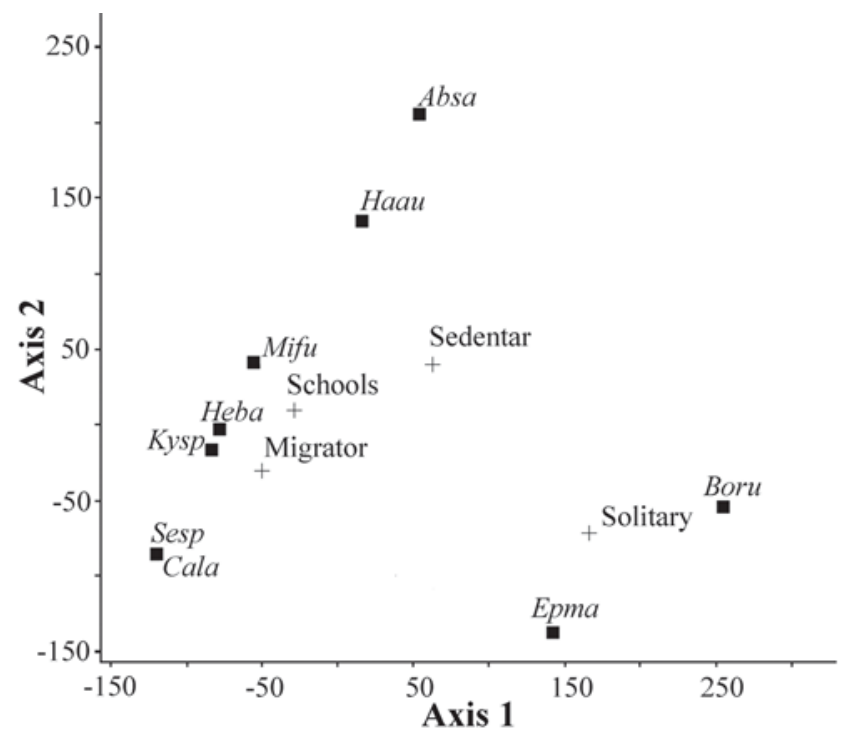

Fig. 5. Ordination plot of the correspondence analysis (first two axes) based on fishermen's answers about migratory behavior of the nine studied fish species in the southeastern Brazilian coast: Absa = Abudefduf saxatilis; Boru $=$ Bodianus rufus; Cala = Caranx latus; Epma = Epinephelus marginatus; Haau = Haemulon aurolineatum $;$ Heba $=$ Hemiramphus balao; Kysp = Kyphosus spp.; Mifu= Micropogonias furnieri; Sesp $=$ Seriola $\mathrm{spp}$.

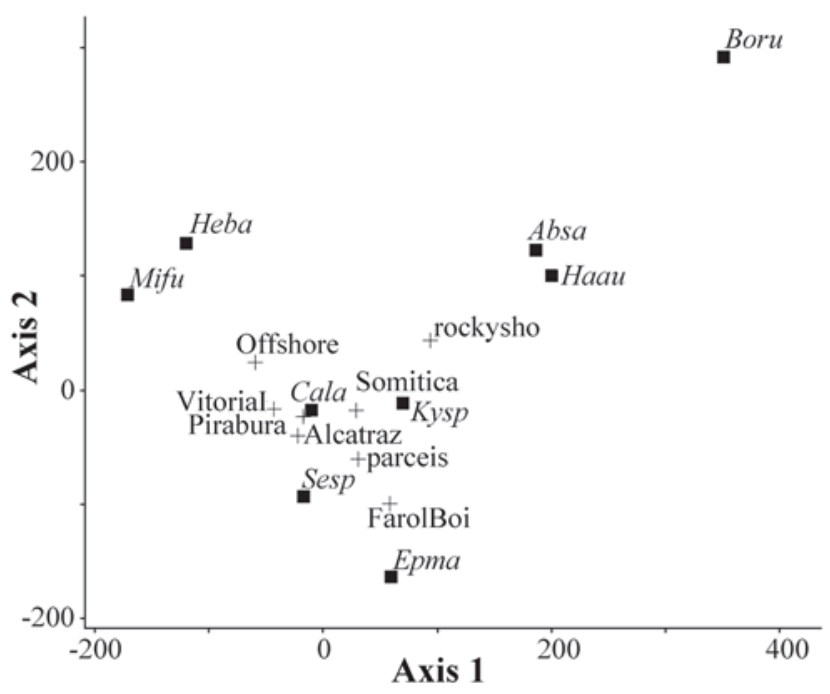

Fig. 6. Ordination plot of the correspondence analysis (first two axes) based on fishermen's answers about migratory routes of the nine studied fish species in the southeastern Brazilian coast: Absa = Abudefduf saxatilis; Boru $=$ Bodianus rufus; Cala = Caranx latus; Epma = Epinephelus marginatus; Haau = Haemulon aurolineatum; Heba = Hemiramphus balao; Kysp = Kyphosus spp.; Mifu= Micropogonias furnieri; Sesp = Seriola $\mathrm{spp}$. 


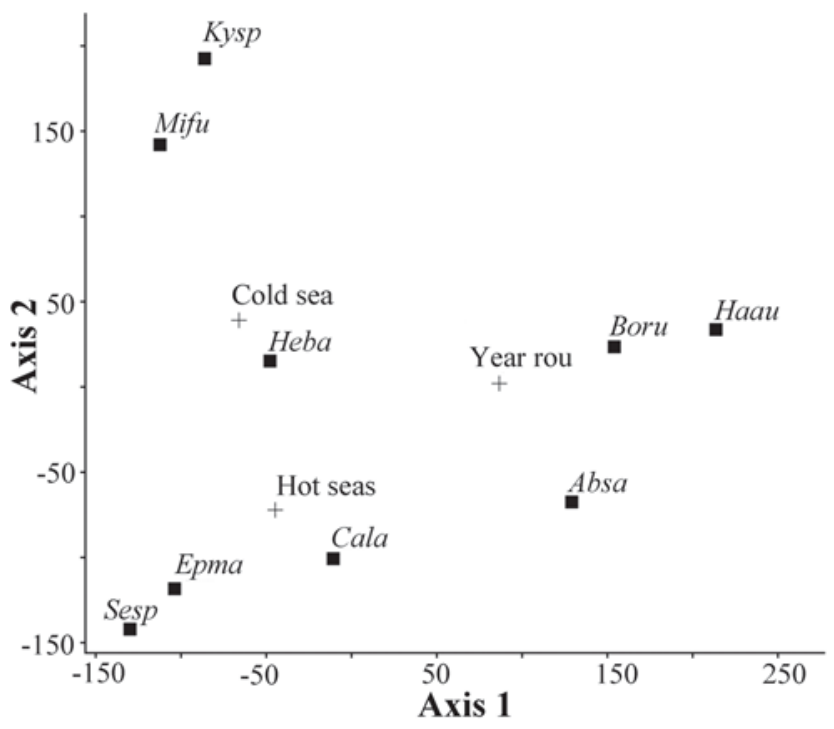

Fig. 7. Ordination plot of the correspondence analysis (first two axes) based on fishermen's answers about fishing season of the nine studied fish species in the southeastern Brazilian coast: Absa $=$ Abudefduf saxatilis; Boru = Bodianus rufus; Cala $=$ Caranx latus $;$ Epma $=$ Epinephelus marginatus; Haau = Haemulon aurolineatum; Heba = Hemiramphus balao; Kysp = Kyphosus spp.; Mifu= Micropogonias furnieri; Sesp = Seriola $\mathrm{spp}$.

comparable quality with data gathered in an extensive biological survey involving stomach content analysis of fish and underwater behavior observations along 14 months at the same region (Gibran, 2007). This highlights the potential of fishermen's LEK to improve biological knowledge and management practices in the absence of biological studies.

Coastal food webs are not easy to elaborate and we lack detailed data on the diet of many Southwestern Atlantic fishes. However, coastal food webs are important for fisheries managers and researchers to have insights on ecological processes, such as patterns of energy flow and potential cascade effects along the food chains, which may be caused by the depletion of fishing stocks (Vasconcellos \& Gasalla, 2001; Scheffer et al., 2005). Fishermen's LEK allowed us to estimate fish trophic levels and to design fish food webs for the southeastern Brazilian coast (Table 3, Fig. 4a,b), which may help scientists and managers to assess complex ecological processes even in the absence of detailed biological information. For example, some fishes, such as Seriola spp. and bluefish, were mentioned by the interviewed fishermen as being predators of both reef and pelagic fishes (Fig 4a,b). Therefore, these fishes may transfer nutrients and biomass between reefs and pelagic habitats, as already observed by biological surveys (Bray \& Miller, 1981). Many of the interviewed fishermen mentioned cephalopods (squids, Loligo spp.) as important food for several fishes, especially Seriola spp. (Fig. 4b). This result indicates that depletion of

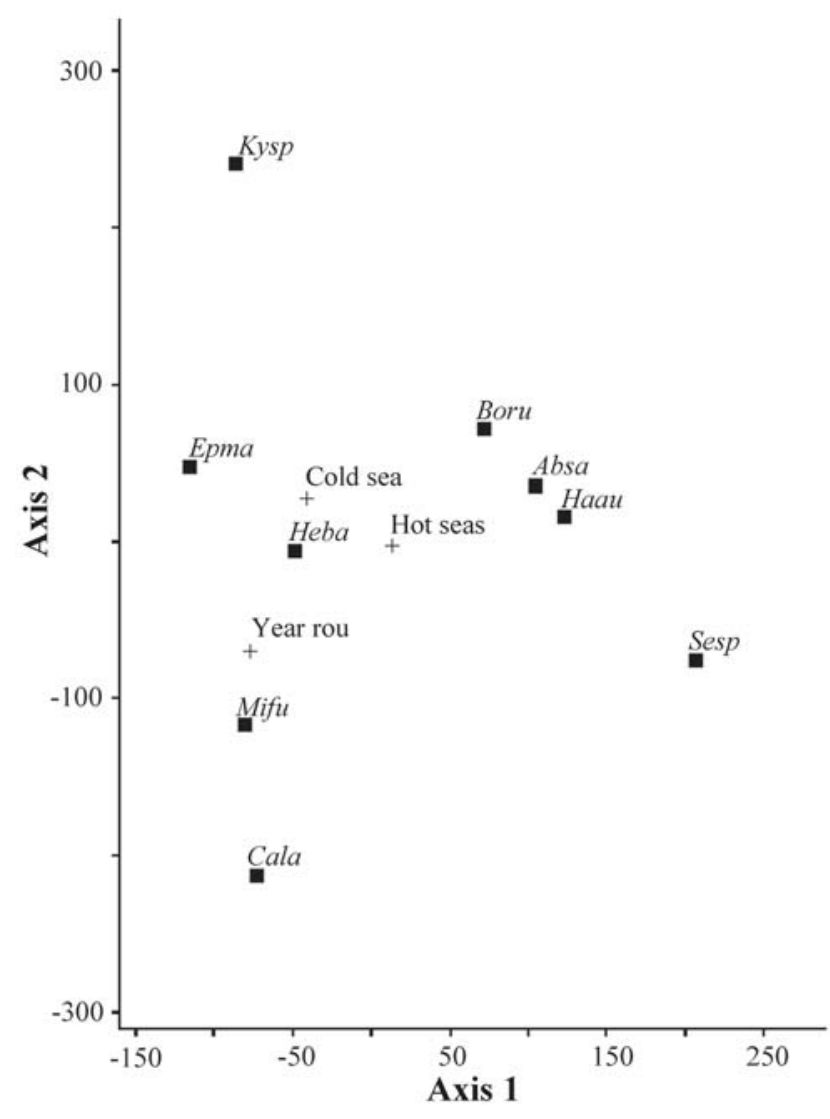

Fig. 8. Ordination plot of the correspondence analysis (first two axes) based on fishermen's answers about reproductive (spawning) season of the nine studied fish species in the southeastern Brazilian coast: Absa=Abudefduf saxatilis; Boru $=$ Bodianus rufus $;$ Cala $=$ Caranx latus $;$ Epma $=$ Epinephelus marginatus; Haau = Haemulon aurolineatum; Heba $=$ Hemiramphus balao; Kysp = Kyphosus spp.; Mifu = Micropogonias furnieri; Sesp = Seriola spp.

squid populations, which have been targeted by Búzios Island fishermen (Begossi, 1996), might potentially affect large commercial fishes. This hypothesis of a trophic link between squids and commercial fishes could be further investigated through biological surveys.

Most of the comparisons we made in this study were based on biological studies addressing the same fish species but in other regions of Brazil or elsewhere, or on surveys addressing other fish species from the same genus. In such context, fishermen's LEK data would reinforce information from biological studies made in other places, besides providing additional support for some biological hypotheses (Silvano \& Valbo-Jørgensen, 2008).

Lack of biological data to be compared with fishermen's LEK. In tropical developing countries fishermen's LEK may be the only available source of information. This was observed in Búzios Island regarding reproduction and migration of most 
of the studied fishes, especially H. balao and Seriola spp., which have been seldom studied in Brazil (Table 5). Most of the interviewed fishermen (61\%) mentioned that $M$. furnieri makes migrations between the Búzios Island and the open ocean (offshore). Albeit there are no detailed migratory surveys of this fish in Brazil, such migratory pattern between off-shore and coastal waters (estuaries) has been observed for this fish in the southern Atlantic Ocean (Uruguay), and this migration is well known by Uruguayan fishers (Norbis, 1995). Furthermore, such migration of M. furnieri has been also mentioned by other Brazilian coastal fishermen (Silvano et al., 2006), which indicates that fishermen from Búzios Island provided reliable and accurate information about this important commercial fish.

Studies on reproduction of commercial fishes are usually lacking in Brazil and in many other tropical developing countries. Many of the interviewed fishermen ignored the fish spawning seasons, and usually the older fishermen were the ones to provide such information. This was surprising, as in other places, such as in the South Pacific, fishermen show a detailed knowledge about the spawning behavior of marine fishes (Johannes, 1981; Johannes et al., 2000). However, LEK is often unevenly shared among fishermen (Johannes et al., 2000), and in other survey including only older and more experienced Brazilian coastal fishermen (40 years or older) we do get more answers about fish reproduction and migration (Silvano et al., 2006). However, even these older fishermen usually do not know the time and place of spawning of some commercial fishes, such as Seriola spp. (Silvano et al., 2006). Therefore, it can be argued that southeastern Brazilian coastal fishermen usually lack knowledge about fish reproduction (Silvano \& Begossi, 2005; Silvano et al., 2006, this study). This raises concerns that fishermen's LEK might be vanishing and older fishermen are not transmitting their knowledge to younger ones, which may be a consequence of recent changes in the lifestyle and economic activities of Brazilian fishers, such as the transition from fishing to tourism (Begossi, 2001).
However, fishermen in Búzios Island and in other places along the southeastern Brazilian coast show a detailed knowledge about fish diet and habitats (Silvano \& Begossi, 2005, 2010, this study), which indicates that at least some knowledge has been transmitted. Other possibility would be that adult spawning fish have become scarce, especially the commercial ones. Therefore, the studied Brazilian coastal fishermen would be exploiting mainly immature fish, which would explain their lack of knowledge about fish spawning patterns (Silvano et al., 2006). Indeed, Búzios Island fishermen mentioned that the abundance of commercial fishes has decreased.

Contradictions between LEK and biological data. Disagreements between fishermen's LEK and biological data may reveal new biological information (Marques, 1991; Johannes et al., 2000; Silvano \& Valbo-Jørgensen, 2008); even considering that sometimes fishermen could be equivocated. There was no consensus among Búzios Island fishermen about the spawning season of E. marginatus: both the hot (31\%) and cold $(13 \%)$ seasons were mentioned. Other survey also found that coastal fishermen from the South, southeastern and northeastern Brazil mentions that E. marginatus spawns during summer, but at least some fishermen mention that it spawns during the cold season (Begossi \& Silvano, 2008). This suggests that E. marginatus may have more than one spawning season along the Brazilian coast, but this fish has not been recorded yet by biologists as spawning during the colder months (Bertoncini et al., 2003). Búzios Island fishermen mentioned that $M$. furnieri spawns during the hot season (mostly during January), while the biological literature indicates that this fish spawns during winter and spring (from June to November) in southeastern Brazil (Vazzoler, 1991). Such disagreement may either indicate that $M$. furnieri has a distinct spawning peak in the studied region, or that this fish may have changed its spawning season since the 1990s.

Reef fishes from the families Serranidae and Lutjanidae, including E. marginatus, may form spawning aggregations:

Table 4. Additional information provided by interviewed fishermen about abundance trends of the studied fishes. Total numbers of interviewed fishermen and scientific names of fish species are in Table 1.

\begin{tabular}{|c|c|c|c|}
\hline Fishes & Abundance trends according to fishermen & $\%$ of fishermen & $\begin{array}{c}\text { Mean age of fishermen (years } \pm \\
\text { standard deviation, when more } \\
\text { than one) }\end{array}$ \\
\hline Kyphosus spp. & Abundant and common & 3 & 63 \\
\hline \multirow[t]{2}{*}{ Epinephelus marginatus } & Abundance declined compared to past levels & 13 & $58( \pm 17)$ \\
\hline & Divers caught too many fish. depleting the fishery & 8 & $56( \pm 23)$ \\
\hline \multirow[t]{2}{*}{ Caranx latus } & Abundance declined compared to past levels & 18 & $53( \pm 15)$ \\
\hline & Abundance declined due to large scale fisheries for sardines (Clupeidae) & 13 & $50( \pm 13)$ \\
\hline Bodianus rufus & Abundant and common & 10 & $39( \pm 13)$ \\
\hline \multirow{3}{*}{ Micropogonias furnieri } & Abundance declined compared to past levels & 7 & $53( \pm 14)$ \\
\hline & Abundance declined due to large scale fisheries for sardines (Clupeidae) & 7 & $53( \pm 14)$ \\
\hline & Abundant and common & 4 & 80 \\
\hline \multirow{3}{*}{ Seriola spp. } & Abundance declined compared to past levels & 32 & $45( \pm 14)$ \\
\hline & Divers caught too many fish. depleting the fishery & 11 & $47( \pm 15)$ \\
\hline & Fishermen catch young fishes & 4 & 37 \\
\hline \multirow{3}{*}{ Hemiramphus balao } & Abundance declined compared to past levels & 4 & 37 \\
\hline & Abundant and common & 4 & 39 \\
\hline & Intensively fished to be used as bait in sport fishing & 14 & $49( \pm 15)$ \\
\hline Haemulon aurolineatum & Abundant and common & 7 & $39( \pm 28)$ \\
\hline
\end{tabular}


several individuals migrate off the reefs and aggregate to spawn in the open sea (Sadovy, 1996). These spawning aggregations have been observed in the Caribbean (Coleman et al., 1996; Sadovy, 1996), Pacific (Johannes, 1981) and Mediterranean (Louisy, 1996), but such behavior has not yet been recorded for E. marginatus in Brazil (Bertoncini et al., 2003). Spawning aggregations have been recorded in the southern Brazilian coast for a closely related species, the mero (Epinephelus itajara), based on fishermen's LEK (Gerhardinger et al., 2009). Although Búzios Island fishermen's LEK indicates that schooling and migration of E. marginatus may be related to spawning aggregations, fishermen did not mention such behavior. Spawning aggregations were neither mentioned in other survey including a larger sample of more experienced fishermen in the southeastern and northeastern Brazilian coasts (Silvano et al., 2006). Therefore, the occurrence of E. marginatus spawning aggregations in Brazil remains an unsettled issue, which deserves further investigation (Silvano et al., 2006; Silvano \& Valbo-Jørgensen, 2008). Our results indicated that the parcéis would be promising habitats to investigate such spawning aggregations (Fig. 3).

\section{How to apply fishermen's LEK in fisheries management?} Albeit fisheries management plans focus on broad scales, fishing resources are usually managed at the local level. Fisheries management in Brazil has been usually based on few inflexible and top-down rules, such as the establishment of closed seasons for shrimp fishery or the fishery closure for the threatened reef species Epinephelus itajara (www.ibama.gov.br). We lack biological and fisheries information about small scale fisheries on the southeastern Brazilian coast (including the studied region) to assess the real needs for fisheries management and regulations. However, the coastal fish in this region have been exploited by several fishing communities, an uncontrolled and unrecorded recreational fishery, plus a large scale commercial fishery. Fisheries management measures in Brazil have been reactive and even delayed regarding the vulnerability of large reef fishes to overexploitation: fishing of E. itajara was only forbidden when populations of this fish declined to critical levels (Gerhardinger et al., 2009). Our data and those from other survey (Begossi \& Silvano, 2008) indicate that other reef fishes, such as $E$. marginatus, may be also in need of urgent management measures. Therefore, it would be reasonable to implement precautionary and adaptive management measures in the studied region, which could well be based on fishermen's LEK (Johannes, 1998; Begossi \& Silvano, 2008; Silvano \& Begossi, 2010). We provided below some potential applications of our results to improve fishery management.

Establishment of new marine protected areas and monitoring efficacy of existing ones. No-take marine protected areas (MPAs) have been considered an effective measure to protect fishing stocks (Gell \& Roberts, 2003). However, MPAs may not work if poorly designed (lack of scientific data) and not properly enforced, besides the fact that MPAs usually imply in socio- economical and political costs in the form of fishing restrictions, which affect local communities (Sale et al., 2005). Therefore, studies on fishermen's LEK have been useful to improve both the design and the acceptance of MPAs among local fishing communities in tropical developing countries (Aswani \& Hamilton, 2004; Bunce et al., 2008). The interviewed fishermen mentioned that the habitat locally know as parcéis is a preferred habitat to commercial fishes, such as C. latus, Seriola spp. and E. marginatus. Therefore, such parcéis at the southeastern Brazilian coast might be ecological equivalents of the deep water reefs in Florida, which maintain large commercial fishes, including Epinephelus spp. and Seriola spp. (Reed, 2002). A survey combining underwater visual censuses of fish and invertebrates with fishers' classification and knowledge on coastal habitat categories in the Solomon Islands show that habitats recognized by fishers have biological sense and could thus be useful to conservation purposes (Aswani \& Lauer, 2006). Fish communities in Brazilian parcéis are largely unknown and the fishermen's LEK data here reported may be the only available evidence of the importance of these habitats to local fisheries. The ecological role of parcéis in supporting populations of large commercial fishes should be checked by further studies and this should be considered when devising new MPAs along the Brazilian coast. The fishing effects of existing MPAs in the southeastern Brazilian coast remain largely unknown. Some of the interviewed fishermen (18\%) mentioned that Seriola spp. is abundant in Alcatrazes Island, which indicates that the isolation (distant from the coast and uninhabited) of this island may have contributed to protect fish populations there, besides a fishing closure imposed by the Brazilian navy.

The interviewed fishermen in Búzios Island mentioned distinct categories of fish mobility, ranging from highly migratory (Seriola spp. and C. latus) to sedentary fish (H. aurolineatum and $B$. rufus). The migratory movements of most of these species are not known, and the fishermen's LEK may thus be the only available information. Such information could fill existing gaps in biological knowledge, besides being useful to support conservation measures, such as definitions of size and shape of MPAs (Chapman \& Kramer, 2000).

Coastal zoning. Búzios Island fishermen mentioned that some commercial fishes occur in specific habitats (Fig. 3). This data, coupled to available mapping of fishing grounds exploited by southeastern Brazilian coastal fishermen (Begossi, 2001, 2006; Begossi \& Silvano, 2008), could and should support the future establishment of exclusive areas for artisanal fisheries, as part of a broad coastal zoning system. This would reduce fishing pressure in exclusive areas by other resource users, such as large-scale commercial fisheries and tourists (divers and other recreational fishers), therefore reducing social conflicts.

Closed seasons to protect spawning fish. We provided some useful and original qualitative information about fish reproduction based on fishermen's LEK, which indicated that all the studied fishes would be spawning mainly during the 
hot season (i.e., summer). Such reproductive season mentioned by the interviewed fishermen agrees with biological literature for some fishes: Seriola lalandi in the Pacific (Australia) (Gillanders et al., 1999), Epinephelus marginatus in South Brazil (Bertoncini et al., 2003), and Hemirhamphus balao in Florida (Berkeley \& Houde, 1978; McBride \& Thurman, 2003). These results of our interviews and the corresponding data from the literature indicate that the summer season (from December to February) would be the more appropriate time to set a closed fishing season to protect spawning fish in the studied region. Local fishermen may accept more easily management measures based on their own knowledge (Bunce et al., 2008). However, fishermen should be consulted about closed fishing periods and income alternatives should be provided during the period of fishing closure. These alternatives could be governmental payments or alternative fishing resources: squids are also commonly caught in Búzios Island during the summer (Begossi, 1996).

Assessing fishing pressure and fish abundance trends over time. Information from local fishermen, especially the older ones, may be useful as an indicator of fishing pressure and of long-term changes in the abundance of exploited fish (Sa'enz-Arroyo et al., 2005). Our survey did not include specific questions about abundance trends of exploited fish, although data on fishing landings is available for Búzios Island (Begossi, 1996). Nevertheless, even not being asked about this, the older interviewed fishermen (mean age above 45 years) mentioned that commercial fishes decreased in abundance, especially Seriola spp., E. marginatus, $M$. furnieri and $C$. latus. Interviewed fishermen usually blamed other groups of fishers, such as large scale commercial purse seine fishermen and divers (sport fishermen) for declines in fish abundance (Table 4). Micropogonias furnieri, which was mentioned in our interviews as being a commercial fish, was not recorded in a previous survey of fish landings in Búzios Island made in 1986 and 1987 (Begossi, 1996). This indicates a possible increase in fisheries for M. furnieri at the studied region, which could be linked to the alleged population decline of other commercial fishes.

Although Búzios Island fishermen may show an accurate LEK about fish stock depletion, the causes of this possible over-fishing acknowledged by fishermen may be at least partially influenced by social and political conflicts (Maurstad et al., 2007). However, even considering such influences, concerns of Búzios Island fishermen and of other Brazilian coastal fishers (Silvano et al., 2006) about declines on fish abundance of commercial fishes, such as Seriola spp. and E. marginatus, should be considered by fisheries managers. Older fishermen were the ones to spontaneously mention decreases on fish abundance (Table 4). These more experienced fishermen would have been fishing for a long enough time to notice such trends (Sa'enz-Arroyo et al., 2005; Bunce et al., 2008). Managers could thus direct research and management to these fishes.
Fishermen's LEK and co-management. Considering the overall inadequacies of top-down management measures, it has been argued that tropical coastal fisheries would be better managed by co-management systems, which involve local fishers and their LEK (Ruddle \& Hickey, 2008). Búzios Island fishermen show some promising features to engage in co-management: low population density, incipient territoriality (exclusive rights to use fishing spots), limited fishing technology and temporal stability in the use of the fishing grounds (Begossi, 1995, 1996, 1998, 2001, 2006). However, a successful co-management would also depend on the political and social organization of the involved local communities, and this organization is still weak among the Caiçara fishing communities (Begossi, 1998). Nevertheless, because the sustainable management initiatives of local fishermen are often grounded on their LEK about fishing resources (Berkes \& Turner, 2006), studies addressing fishermen's LEK can be considered as an important first step towards co-management.

A brief search in two popular internet sites for research articles (ISI and Scielo) indicated the paucity of published surveys about the nine studied fish species: the better known fishes, such as Micropogonias furnieri and some reef fishes, have roughly one third of published studies made in Brazil (Table 5). However, for all the studied fishes, the amount of studies retrieved using the keywords 'biology' and 'ecology' was remarkably low (Table 5), which indicates that most of the existing surveys probably focus on other subjects, such as fisheries, genetics, taxonomy, among others. Only for comparison, a search for Gadus morhua (cod) in ISI yielded a total of 6016 articles, 201 with the keyword 'ecology' and 119 with the keyword 'biology'. Therefore, there are more published studies about a single commercial temperate fish species than for all the Brazilian coastal fishes addressed in our survey (Table 5). Moreover, some important commercial fishes in Brazil, such as Seriola spp., E. marginatus and C. latus remain poorly studied there $(8 \%$ or less of the published articles in Brazil) and some fishes, such as $H$. balao and reef fishes, have been seldom studied elsewhere (Table 5). Therefore, in such a context of barely needed biological and ecological knowledge about coastal fishes to support management decisions, we provided a broad fishermen's LEK data-base about these tropical fishes.

\section{Acknowledgements}

We thank to the Caiçaras from Búzios Island for their valuable cooperation with this research, especially Aristides, Ditinha, Anacleto and Cida; to FAPESP (São Paulo, Brazil) for scholarships and grants to RAMS (97/04446-9 and 01/072474), and to $\mathrm{AB}(01 / 14526-7)$; to $\mathrm{CNPq}$ (Brazil) for a productivity research grant to authors; to Jansen A. S. Zuanon, Ivan Sazima, José L. Figueiredo, Walter Barrela, José G.. W. Marques, and Shankar Aswani for useful comments and suggestions on earlier versions of this manuscript. 
Table 5. Search results for scientific publications about the studied fishes, using two search engines on July 2010: ISI Web of Science (http://apps.isiknowledge.com) and Scielo (http://www.scielo.org), which includes Brazilian journals that may not appear on ISI. Total hits are total number of articles found, plus hits found using the key-words: ecology, biology and Brazil or Brazilian.

\begin{tabular}{|c|c|c|c|c|c|c|}
\hline Fish species & Total hits ISI & Ecology ISI & Biology ISI & Brazil ISI & $\%$ Brazilian surveys ISI & Total hits Scielo \\
\hline Seriola spp. & 720 & 7 & 13 & 1 & 0.14 & 0 \\
\hline Micropogonias furnieri & 124 & 8 & 8 & 41 & 33.1 & 30 \\
\hline Epinephelus marginatus & 98 & 6 & 4 & 8 & 8.2 & 4 \\
\hline Kyphosus spp. & 80 & 5 & 1 & 2 & 2.5 & 1 \\
\hline Abudefduf saxatilis & 43 & 4 & 4 & 9 & 20.9 & 4 \\
\hline Caranx latus & 23 & 0 & 1 & 2 & 8.7 & 2 \\
\hline Haemulon aurolineatum & 18 & 1 & 0 & 5 & 27.8 & 2 \\
\hline Bodianus rufus & 10 & 1 & 1 & 3 & 30 & 0 \\
\hline Hemiramphus balao & 3 & 0 & 3 & 0 & 0 & 0 \\
\hline Total & 1119 & 32 & 35 & 71 & 6.3 & 43 \\
\hline
\end{tabular}

\section{Literature Cited}

Adams, C. 2000. As populações Caiçaras e o mito do bom selvagem: a necessidade de uma nova abordagem interdisciplinar. Revista de Antropologia, 43: 145-182.

Aswani, S. \& R. Hamilton. 2004. Integrating indigenous ecological knowledge and customary sea tenure with marine and social science for conservation of bumphead parrotfish (Bolbometopon muricatum) in the Roviana Lagoon, Solomon Islands. Environmental Conservation, 31: 1-15.

Aswani, S. \& M. Lauer. 2006. Benthic mapping using local aerial photo interpretation and resident taxa inventories for designing marine protected areas. Environmental Conservation, 33: 263-273.

Barreiros, J. P. \& R. S. Santos. 1998. Notes on the food habits and predatory behaviour of the dusky grouper, Epinephelus marginatus (Lowe, 1834) (Pisces: Serranidae) in the Azores. Arquipélago, Ciências Biológicas e Marinhas, 16A: 29-35.

Begossi, A. 1992. Food taboos at Búzios Island (SE Brazil): their significance and relation to folk medicine. Journal of Ethnobiology, 12: 117-139.

Begossi, A. 1995. Fishing spots and sea tenure: incipient forms of local management in Atlantic Forest coastal communities. Human Ecology, 23: 387-406.

Begossi, A. 1996. Fishing activities and strategies at Búzios Island (Brasil). Pp. 125-141. In: Meyer, R. M., C. Zhang, M. L. Windsor, B. J. McCay, L. J. Hushak \& R. M. Muth (Eds.). Proceedings of the World Fisheries Congress, Theme 2, Atenas. New Delhi, Oxford \& IBH Publishing.

Begossi, A. 1998. Cultural and ecological resilience among Caiçaras of the Atlantic Forest and caboclos of the Amazon, Brazil. Pp. 129-157. In: Folke, C. \& F. Berkes (Eds.). Linking social and cultural systems for resilience. Cambridge, Cambridge University Press.

Begossi, A. 2001. Mapping spots: fishing areas and territories in the Atlantic Forest coast, Brazil. Regional Environmental Change, 2: 1-12.

Begossi, A. 2006. Temporal stability in fishing spots: conservation and co-management in Brazilian artisanal coastal fisheries. Ecology \& Society 11: 5 .

Begossi, A. \& J. L. Figueiredo, 1995. Ethnoichthyology of southern coastal fishermen: cases from Búzios Island and Sepetiba Bay (Brazil). Bulletin of Marine Sciences, 56: 710-717.

Begossi, A. \& P. J. Richerson. 1993. Biodiversity, family income and ecological niche: a study on the consumption of food animals at Búzios Island. Ecology of Food and Nutrition, 30: 51-61.
Begossi, A. \& R. A. M. Silvano. 2008. Ecology and ethnoecology of dusky grouper garoupa, Epinephelus marginatus (Lowe, 1834) along the coast of Brazil. Journal of Ethnobiology and Ethnomedicine, 4: 20.

Berkeley, S. A. \& E. D. Houde. 1978. Biology of two exploited species of halfbeaks, Hemiramphus brasiliensis and H. balao from Southeast Florida. Bulletin of Marine Sciences, 28: 624644.

Berkes, F. \& N. J. Turner. 2006. Knowledge, learning and the evolution of conservation practice for social-ecological system resilience. Human Ecology, 34: 479-494.

Bertoncini, A. A., L. F. Machado, M. Hostim-Silva \& J. P. Barreiros. 2003. Reproductive biology of the dusky grouper Epinephelus marginatus (Lowe, 1834). Brazilian Archives of Biology and Technology, 46: 373-381.

Bray, R. N. \& A. C. Miller. 1981. The fish connection: a trophic link between planktonic and rocky reef communities? Science, 214: 204-205.

Bunce, M. L. D. Rodwell, R. Gibb \& L. Mee. 2008. Shifting baselines in fishers' perceptions of island reef fishery degradation. Ocean \& Coastal Management, 51: 285-302.

Chapman, M. R. \& D. L. Kramer, 2000. Movements of fishes within and among fringing coral reefs in Barbados. Environmental Biology of Fishes 57: 11-24.

Coleman, F. C., C. C. Koenig \& L. A. Collins. 1996. Reproductive styles of shallow-water groupers (Pisces: Serranidae) in the eastern Gulf of Mexico and the consequences of fishing spawning aggregations. Environmental Biology of Fishes 47: 129-141.

Diegues, A. C. 1998. Environmental impact assessment: the point of view of artisanal fishermen communities in Brazil. Ocean \& Coastal Management, 39: 119-133.

Ferreira, C. E. L., S. R. Floeter, J. L. Gasparini, B. P. Ferreira \& J. C. Joyeux. 2004. Trophic structure patterns of Brazilian reef fishes: a latitudinal comparison. Journal of Biogeography, 31: 1093-1106.

Figueiredo, J. L. \& N. A. Menezes. 1978. Manual de Peixes Marinhos do Sudeste do Brasil, II. Teleostei (1). São Paulo, MZUSP, 110p.

Figueiredo, J. L. \& N. A. Menezes. 1980. Manual de Peixes Marinhos do Sudeste do Brasil, III. Teleostei (2). São Paulo, MZUSP, 90p.

Figueiredo, J. L. \& N. A. Menezes. 2000. Manual de Peixes Marinhos do Sudeste do Brasil, VI. Teleostei (5). São Paulo, MZUSP, 116p.

Figueiredo, G. M. \& J. P. Vieira. 2005. Diel feeding, daily food consumption and the predatory impact of whitemouth croaker 
(Micropogonias furnieri) in an estuarine environment. Marine Ecology, 26: 130-139.

Froese, R. \& D. Pauly. 2011. FishBase. World Wide Web electronic publication (Version 01/2011). Available at: www.fishbase.org. Accessed in June 2011.

Gell, F. R. \& C. M. Roberts. 2003. Benefits beyond boundaries: the fishery effects of marine reserves. TRENDS in Ecology and Evolution, 18: 448-455.

Gerhardinger, L. C., M. Hostim-Silva, R. P. Medeiros, J. Matarezi, A. A. Bertoncini, M. O. Freitas \& B. P. Ferreira. 2009. Fishers' resource mapping and goliath grouper Epinephelus itajara (Serranidae) conservation in Brazil. Neotropical Ichthyology, 7: 93-102.

Gibran, F.Z. 2007. Activity, habitat use, feeding behavior, and diet of four sympatric species of Serranidae (Actinopterygii: Perciformes) in southeastern Brazil. Neotropical Ichthyology, 5: 387-398.

Gillanders, B. M., D. J. Ferrell \& N. L. Andrew. 1999. Size at maturity and seasonal changes in gonad activity of yellowtail kingfish (Seriola lalandi: Carangidae) in New South Wales, Australia. New Zealand Journal of Marine and Freshwater Research, 33: 457-468.

Huntington, H. P., R. S. Suydam \& D. H. Rosemberg. 2004. Traditional knowledge and satellite tracking as complementary approaches to ecological understanding. Environmental Conservation, 31: 177-180.

Johannes, R. E. 1981. Working with fishermen to improve coastal tropical fisheries and resource management. Bulletin of Marine Sciences, 31: 673-680.

Johannes, R. E. 1998. The case for data-less marine resource management: examples from tropical nearshore finfisheries. TRENDS in Ecology and Evolution, 13: 243-246.

Johannes, R. E., M. M. R. Freeman \& R. J. Hamilton. 2000. Ignore fishers' knowledge and miss the boat. Fish and Fisheries, 1: 257-271.

Louisy, P. 1996. Principaux patrons de coloration du mérou brun de Mediterranée Epinephelus marginatus (Lowe, 1834) (Pisces, Serranidae) en période d'activité reproductrice. Revue Française d'Aquariologie, 23: 21-32.

Marques, J.G.W. 1991. Aspectos Ecológicos na Etnoictiologia dos Pescadores do Complexo Estuarino-lagunar de Mundaú Manguaba, Alagoas. Unpublished Ph.D. Dissertation, Universidade Estadual de Campinas, Campinas.

Maurstad, A., T. Trine Dale \& P. A. Bjørn. 2007. You Wouldn’t Spawn in a Septic Tank, Would You? Human Ecology, 35: 601-610.

McBride, R. S. \& P. E. Thurman. 2003. Reproductive Biology of Hemiramphus brasiliensis and H. balao (Hemiramphidae): Maturation, Spawning Frequency, and Fecundity. Biological Bulletin, 204: 57-67.

McCune, B. \& M. J. Mefford. 1997. Multivariate Analysis of Ecological Data. Version 3.11. MjM software, Gleneden Beach, U.S.A.

Menezes, N. A. \& J. L. Figueiredo. 1980. Manual de peixes marinhos do sudeste do Brasil, IV (3). São Paulo, MZUSP, 96p.

Morril, W. T. 1967. Ethnoichthyology of the Cha-Cha. Ethnology, 6: 405-417.

Norbis, W. 1995. Influence of wind, behaviour and characteristics of the croaker (Micropogonias furnieri) artisanal fishery in the Rio de la Plata (Uruguay). Fisheries Research, 22: 43-58.

Pauly, D., V. Christensen, S. Guénette, T. J. Pitcher, U. R. Sumaila, C. J. Walters, R. Watson \& D. Zeller. 2002. Towards sustainability in World Fisheries. Nature, 418: 689-695.
Pipitone, C. \& F. Andaloro. 1995. Food and feeding habits of juvenile greater Amberjack, Seriola dumerili (Osteichthyes, Carangidae) in inshore waters of the Central Mediterranean Sea. Cybium, 19: 305-310.

Poizat, G. \& E. Baran. 1997. Fishermen's knowledge as background information in tropical fish ecology: a quantitative comparison with fish sampling results. Environmental Biology of Fishes, 50: 435-449.

Randall, J. E. 1967. Food habits of reef fishes of the West Indies. Studies on Tropical Oceanography, 5: 665-847.

Reed, J. K. 2002. Deep-water Oculina coral reefs of Florida: biology, impacts, and management. Hydrobiologia, 471: 43-55.

Ruddle, K. \& F. R. Hickey. 2008. Accounting for the mismanagement of tropical nearshore fisheries. Environment Development and Sustainability, 10: 565-589.

Sadovy, Y. J. 1996. Reproduction of reef fishery species. Pp. 1559. In: Polunin, N. V. C. \& C. M. Roberts (Eds.). Reef Fisheries. London, Chapman \& Hall.

Sa'enz-Arroyo, A., C. M. Roberts, J. Torre \& M. Carinõ-Olvera. 2005. Using fishers' anecdotes, naturalists' observations and grey literature to reassess marine species at risk: the case of the Gulf grouper in the Gulf of California, Mexico. Fish and Fisheries, 6: 121-133.

Sale, P. F., R. K. Cowen, B. S. Danilowicz, G. P. Jones, J. P. Kritzer, K. C. Lindeman, S. Planes, N. V. C. Polunin, G. R. Russ, Y. J. Sadovy $\&$ R. S. Steneck. 2005. Critical science gaps impede use of no-take fishery reserves. TRENDS in Ecology and Evolution, 20: 74-80.

Sazima, I. 1986. Similarities in feeding behaviour between some marine and freshwater fishes in two tropical communities. Journal of Fish Biology 29, 53-65.

Scheffer, M., S. Carpenter \& B. de Young. 2005. Cascading effects of overfishing marine systems. TRENDS in Ecology and Evolution, 20: 579-581.

Silvano, R. A. M. 2001. Feeding habits and feeding interespecific associations of Caranx latus (Carangidae) in a subtropical reef. Environmental Biology of Fishes, 60: 465-470.

Silvano, R. A. M. \& A. Begossi. 2002. Ethnoichthyology and fish conservation in the Piracicaba River (Brazil). Journal of Ethnobiology, 22: 285-306.

Silvano, R. A. M. \& A. Begossi. 2005. Local knowledge on a cosmopolitan fish, ethnoecology of Pomatomus saltatrix (Pomatomidae) in Brazil and Australia. Fisheries Research 71: 43-59.

Silvano, R. A. M. \& A. Begossi. 2010. What can be learned from fishers? An integrated survey of fishers' local ecological knowledge and bluefish (Pomatomus saltatrix) biology on the Brazilian coast. Hydrobiologia, 637: 3-18.

Silvano, R. A. M., M. A. Gasalla \& S. P. Souza. 2009. Applications of Fishers' Local Ecological Knowledge to Better Understand and Manage Tropical Fisheries. Pp. 76-100. In: Lopes, P. \& A. Begossi (Eds.). Current Trends in Human Ecology. Newcastle upon Tyne, Cambridge Scholars Publishing.

Silvano, R. A. M. \& A. Z. Güth. 2006. Diet and Feeding Behavior of Kyphosus spp. (Kyphosidae) in a Brazilian Subtropical Reef. Brazilian Archives of Biology and Technology, 49: 623-629.

Silvano, R. A. M., P. F. L. MacCord, R. V. Lima \& A. Begossi. 2006. When Does this Fish Spawn? Fishermen's Local Knowledge of Migration and Reproduction of Brazilian Coastal Fishes. Environmental Biology of Fishes, 76: 371-386.

Silvano, R. A. M., A. L. Silva, M. Cerone \& A. Begossi. 2008. Contributions of Ethnobiology to the conservation of tropical rivers and streams. Aquatic Conservation, Marine and 
Freshwater Ecosystems, 18: 241-260.

Silvano, R. A. M. \& J. Valbo-Jørgensen. 2008. Beyond fishermen's tales: contributions of fishers' local ecological knowledge to fish ecology and fisheries management. Environment Development and Sustainability, 10: 657-675.

Vasconcellos, M. \& M. A. Gasalla. 2001. Fisheries catches and the carrying capacity of marine ecosystems in southern Brazil. Fisheries Research, 50: 279-295.
Vazzoler, A. E. A. M. 1991. Síntese de conhecimentos sobre a biologia da corvina, Micropogonias furnieri (Desmarest, 1823), da Costa do Brasil. Atlântica, 13: 55-74.

Submitted July 22, 2010

Accepted October 11, 2011

Published March 30, 2012

Appendix 1. Habitats of studied fishes according to interviewed fishermen. Numbers are percent of fishermen who mentioned each habitat (total numbers of interviewees are in Table 1).

\begin{tabular}{|c|c|c|c|c|c|c|c|c|c|}
\hline Habitats & Seriola spp. & E. marginatus & H. balao & C. latus & M. furnieri & Kyphosus spp. & A. saxatilis & H. aurolineatum & B. rufus \\
\hline Bottom & 36 & 67 & - & 26 & 93 & 33 & 14 & 64 & 28 \\
\hline Mud & - & 3 & - & 3 & 57 & - & - & - & - \\
\hline Sand & 11 & 8 & 29 & 26 & 54 & 5 & 11 & 18 & 5 \\
\hline Boulders & - & 5 & - & 3 & 11 & - & - & 4 & - \\
\hline Holes (crevices) & - & 46 & - & - & - & 5 & 4 & - & 10 \\
\hline Rocks (reefs) & 82 & 95 & 86 & 72 & 4 & 82 & 100 & 96 & 95 \\
\hline Rocky shore & 79 & 87 & 86 & 69 & 7 & 100 & 100 & 100 & 97 \\
\hline "Parcel" & 82 & 64 & - & 46 & 11 & 26 & 14 & 32 & 13 \\
\hline Shallow & 36 & 5 & 93 & 46 & 4 & 41 & 32 & 14 & 49 \\
\hline Shallow and bottom & 32 & 5 & 7 & 26 & 7 & 23 & 54 & 21 & 8 \\
\hline Open sea (pelagic) & 36 & 10 & 43 & 46 & 96 & 5 & 4 & 7 & - \\
\hline
\end{tabular}

